Original Research

\title{
Evaluasi Pengelolaan dan Pemantauan Lingkungan Hidup Dampak Pembangunan Pasar Kahayan Kota Palangka Raya
}

\author{
Tri Budiyanti ${ }^{1,2,}{ }^{*}$, Basuki $^{3}$, Abdul Mukti $^{3}$ \\ ${ }^{1}$ Mahasiswa Program Studi Pengelolaan Sumberdaya Alam dan Lingkungan Universitas Palangka Raya \\ ${ }^{2}$ PNS di Sekretariat Daerah Kota Palangka Raya \\ ${ }^{3}$ Dosen Program Studi Pengelolaan Sumberdaya Alam dan Lingkungan Universitas Palangka Raya \\ * Korespondensi: Tri Budiyanti (Email: tribudiyantioya@gmail.com)
}

\begin{abstract}
This study aims to evaluate the process of environmental management and monitoring as a result of the development of the Kahayan Market, which actually has environmental documents. Aspects assessed include community perceptions, water quality and water biota (plankton), and the impact of the development of the Kahayan Market in Palangka Raya City in general. Based on the provisions, the implementation of environmental management and monitoring is carried out by the Palangka Raya City Public Works and Spatial Planning Agency as a joint Initiator with the Kahayan Market Manager/Government Market UPTD. These activities were not carried out, so there was no reporting and evaluation of management and monitoring. Laboratory analysis of physical parameters, namely suspended solids (TSS) at observation point A-2, shows that the water condition has passed the Class II water quality standard required by PP No. 82 of 2001, amounting to $50 \mathrm{mg} / \mathrm{l}$. Analysis of chemical parameters shows that the water chemistry conditions have exceeded the Class II water quality standards required by PP No. 82 of 2001, namely BOD content of $3 \mathrm{mg} / \mathrm{l}$; and COD content of $100 \mathrm{mg} / \mathrm{l}$. Total Coliform at the A-1 observation point was 16,000 MPN/100 ml and at the A-2 point was 92,000 MPN/ml. Other chemical parameters such as Phosphate, and Ammonia content have also exceeded the established standard.
\end{abstract}

Keywords

Evaluation, management, monitoring, impacts, BOD, COD, total Caliform, Phosphate, Ammonia content, market

\section{PENDAhUluan}

Kota Palangka Raya terus berkembang seiring dengan laju perkembangan ekonomi dan pendudunya. Pemerintah kota sebagai penyedia fasilitas publik harus menyediakan berbagai fasilitas pendukung utilitas kota seperti bangunan komersial pasar yang dapat memaksimalkan fungsi pelayanan jasa perdagangan. Pasar merupakan salah satu fasilitas umum yang sangat penting dan diperlukan oleh masyarakat untuk memenuhi kebutuhannya. Keberadaan pasar memiliki peranan strategis dalam menggerakkan roda perekonomian daerah. Sejalan dengan kecenderungan dan tuntutan pembangunan perkotaan berkelanjutan dan berwawasan lingkungan, keberadaan dan pembangunan pasar dibangun dengan memperhatikan aspek lingkungan.

Pembangunan fisik yang tidak didukung oleh usaha kelestarian lingkungan akan mempercepat proses kerusakan alam yang sebagian besar diakibatkan oleh kegiatan dan perilaku manusia itu sendiri yang tidak berwawasan lingkungan. Untuk itu perlu diupayakan suatu bentuk pembangunan berkelanjutan. Pembangunan berkelanjutan adalah pembangunan yang mewujudkan (memenuhi) kebutuhan hidup saat ini tanpa mengurangi (mengorbankan) kemampuan generasi mendatang untuk mewujudkan kebutuhan hidupnya. Pelaksanaan pembangunan ekonomi yang berkeadilan sosial dilakukan tanpa mengorbankan lingkungan, sehingga pembangunan yang dilaksanakan harus sudah memikirkan pula kebutuhan hidup generasi berikutnya (Sudarwanto, 2018).

Pembangunan yang berwawasan lingkungan tidak akan tercapai hanya melalui hukum lingkungan tetapi membutuhkan penerapan beragam mekanisme formal dan informal. Undang-Undang Nomor 32 tahun 2009 tentang Perlindungan dan Pengelolaan Lingkungan Hidup menyatakan bahwa setiap usaha dan/atau 
kegiatan haruslah mematuhi peraturan dan ketentuan tersebut, termasuk pembangunan kegiatan perdagangan berupa pasar. Pemerintah telah memberikan acuan dalam penyusunan Dokumen Lingkungan yaitu Peraturan Menteri Negara Lingkungan Hidup Republik Indonesia Nomor 16 Tahun 2012 tentang Pedoman Penyusunan Dokumen Lingkungan Hidup.

Pasar Kahayan Kota Palangka Raya yang sudah memiliki dokumen lingkungan berupa Upaya Pengelolaan Lingkungan dan Upaya Pemantauan Lingkungan (UKL-UPL). Pasar Kahayan berlokasi diwilayah Kelurahan Palangka, Kecamatan Jekan Raya pada tahun 2006 direhabilitasi bangunannya dan dibangun dari dana pinjaman Bank Dunia melalui USDRP. Pasar Kahayan terletak berdekatan dengan kawasan padat penduduk dengan aktifitas yang cukup ramai. Kondisi pasar Kahayan saat ini memberi dampak positif dan negatif bagi lingkungan. Dampak negatif yang timbul adalah sampah yang dibuang sembarangan. Membuang sampah sembarangan mengakibatkan bau tidak sedap, merusak keindahan, dan dapat merusak lingkungan sekitarnya. Sampah cair maupun padat dibuang kesaluran air akan mengakibatkan kualitas air menurun dan mengakibatkan terganggunya kehidupan biota air.

Dampak negatif yang ditimbulkan dari aktivitas Pasar Kahayan, maka dilakukan evaluasi terhadap pengelolaan dan pemantauan lingkungan hidup dengan membandingkan keadaan dahulu dan sekarang. Dokumen UKL-UPL dapat menjadi parameter penelitian. Setelah selesainya dokumen UKL-UPL dan izin lingkungan, pembangunan pasar Kahayan sampai saat ini tidak pernah dievaluasi dan laporan pengelolaan dan pemantauan lingkungan hidup tidak pernah juga dilaporkan kepada Instansi terkait yang membidangi lingkungan hidup. Penelitian ini bertujuan untuk menganalisis evaluasi pengelolaan dan pemantauan lingkungan hidup dampak pembangunan Pasar Kahayan yang telah memiliki dokumen lingkungan serta mengetahui sejauhmana keterlibatan masyarakat dalam pengelolaan dan pemantauan lingkungan hidup dampak pembangunan Pasar Kahayan.

\section{METODOLOGI}

Penelitian ini merupakan penelitian yang bersifat deskriptif dengan menggunakan metode survei dan studi kepustakaan yang dilaksanakan di Pasar Kahayan Kelurahan Palangka pada Kecamatan Jekan Raya Kota Palangka Raya selama 3 (tiga) yaitu bulan OktoberDesember 2019 yang meliputi pelaksanaan pengelolaan dan pemantauan lingkungan hidup, pelaksanaan pengawasan yang dilakukan oleh Pemerintah Kota Palangka Raya dan keterlibatan masyarakat terhadap pelaksanaan pengelolaan dan pemantauan lingkungan.

Teknik pengumpulan data dalam penelitian ini terdiri dari studi literatur, observasi, penyebaran kuisioner, wawancara serta pengambilan sampel air. Data yang digunakan bersumber dari data primer dan data sekunder. Data primer yang digunakan berupa hasil kuesioner, observasi, wawancara dengan responden yang terdiri dari pemrakarsa, masyarakat, instansi teknis yang terkait selaku pembina dan pengawas dalam penyelenggaraan pengelolaan dan pemantauan lingkungan hidup serta hasil pengukuran kualitas dan biota air. data Sekunder data yang dikumpulkan melalui studi pustaka dan data-data yang diperoleh dari dinasdinas instansi yang berkaitan langsung dengan penyelenggaraan pengelolalaan dan pengawasan Pembangunan Pasar Kahayan Kota Palangka Raya. Analisis data dideskripsikan dengan melakukan perhitungan skor dari setiap variabel dan total skor dari seluruh variabel menggunakan skala Likert.

Tabel 1. Responden penelitian

\begin{tabular}{|c|c|c|}
\hline No. & Responden & Jumlah \\
\hline 1. & Masyarakat & 40 Orang \\
\hline 2. & Pengelola Pasar & 3 Orang \\
\hline 3. & Dinas Lingkungan Hidup & 3 Orang \\
\hline 4. & DPUPR & 3 Orang \\
\hline 5. & Dinas Kesehatan & 3 Orang \\
\hline \multirow[t]{2}{*}{6.} & $\begin{array}{l}\text { Dinas Pertanian Sub Dinas } \\
\text { Perikanan }\end{array}$ & 3 Orang \\
\hline & Total Responden & 55 Orang \\
\hline
\end{tabular}

\section{HASIL}

\subsection{Evaluasi Pelaksanaan Pengelolaan Lingkungan Hidup Dampak Pembangunan Pasar Kahayan}

Dinas Pekerjaan Umum dan Penataan Ruang Kota Palangka Raya sampai saat ini tidak pernah melaksanakan kewajibannya untuk melaporkan pelaksanaan Dokumen UKL-UPL secara berkala yang dilakukan setiap 6 (enam) bulan dampak pembangunan Pasar Kahayan. Pemrakarsa kegiatan tidak taat terhadap pelaporan pengelolaan lingkungan dengan frekuensi pengelolaan 6 (enam) bulan sekali. Sehingga berdasarkan evaluasi pelaksanaan pengelolaan lingkungan hidup dampak pembangunan Pasar Kahayan masih belum dilaksanakan secara berkala dan kontinyu. Didalam rona awal pada dokumen lingkungan terdapat upaya pengelolaan lingkungan dengan pembangunan dan pengoperasian IPAL, mengatur pembuangan sampah dan pembersihan lahan. Untuk kegiatan yang dilakukan Dinas Pekerjaan Umum dan Penataan Ruang masih belum mengimplementasikan dikarenakan belum dibangunnya IPAL dan masih banyak sampah yang mengendap pada tempat pembuangan. Dinas Pekerjaan Umum dan Penataan Ruang pernah melakukan kegiatan pembersihan didaerah pembuangan tetapi tidak dilakukan secara berkala. 


\subsection{Evaluasi Pelaksanaan Pemantauan Lingkungan Hidup Dampak Pembangunan Pasar Kahayan}

Berdasarkan hasil wawancara dengan pihak dari Dinas Lingkungan Hidup Kota Palangka Raya, bahwa tim dari Dinas Lingkungan Hidup sudah melakukan pengawasan dan pemantauan terhadap dampak pembangunan Pasar Kahayan Kota Palangka Raya dan berdasarkan wawancara yang dilakukan dengan pejabat di Dinas Kesehatan Kota Palangka Raya bahwa Pemrakarsa dalam hal ini Dinas Pekerjaaan Umum dan Tata Ruang Kota Palangka Raya tidak pernah menyampaikan laporan pemantauan lingkungan hidup berdasarkan Dokumen UKL-UPL, tetapi Dinas Kesehatan Kota Palangka Raya secara berkala selalu melakukan pemantauan ke Pasar Kahayan dengan kegiatan yang lain. Hasil wawancara dengan pejabat di Dinas Perikanan Kota Palangka Raya didapat informasi bahwa Dinas Pekerjaan Umum dan Penataan Ruang Kota Palangka Raya tidak pernah menyampaikan laporan pemantauan lingkungan hidup. Terkait pemantauan lingkungan oleh Dinas Lingkungan Hidup, Dinas Kesehatan dan Dinas Perikanan Kota Palangka Raya disajikan dalam Tabel 2.

\subsection{Pelaksanaan Pengelolaan dan Pemantauan Lingkungan Hidup}

Hasil wawancara dengan pejabat Dinas Pekerjaan Umum dan Penataan Ruang Kota Palangka Raya bahwa pejabat yang ada saat ini tidak mengetahui adanya kepemilikan dokumen UKL-UPL untuk pembangunan Pasar Kahayan sehingga tidak dapat memberikan keterangan sesuai dengan pertanyaan yang ada dalam kuesioner, hal ini disebabkan pejabat yang dulu menangani dan mengetahui kegiatan Pembangunan Pasar Kahayan sudah dipindah tugas atau mutasi, sehingga untuk pemantauan dan pelaporan terhadap aspek penyelenggaraan pengelolaan dan pemantauan lingkungan hidup tidak pernah dilakukan. Didalam dokumen lingkungan terdapat surat pernyataan dari pemrakarsa yang menyatakan bahwa pemrakarsa bersedia melakukan pengelolaan dan pemantauan lingkungan sesuai dengan yang tercantum dalam dokumen UKL-UPL serta bersedia dipantau dampaknya oleh instansi/pihak yang berwenang sesuai dengan peraturan yang berlaku.

Tabel 2. Pemantauan terhadap lingkungan hidup

\begin{tabular}{|c|c|c|c|c|}
\hline Variabel & Kriteria & Sub Kriteria & Frekuensi & Persentase (\%) \\
\hline Kualitas Air & & $\begin{array}{l}\text { - Pemrakarsa Melaksanakan semua } \\
\text { persyaratan dan kewajiban dalam Dokumen }\end{array}$ & - & \\
\hline \multirow[t]{7}{*}{$\begin{array}{l}\text { Gangguan } \\
\text { terhadap } \\
\text { Biota Air }\end{array}$} & Implementasi & $\begin{array}{l}\text { - Lingkungan } \\
\text { Pemrakarsa Tidak melaksanakan semua } \\
\text { persyaratan dan kewajiban dalam Dokumen } \\
\text { Lingkungan }\end{array}$ & 9 & 100,00 \\
\hline & Pelaporan & - Rutin melakukan pelaporan & - & \\
\hline & & - Melakukan pelaporan tetapi tidak rutin & - & \\
\hline & & - Tidak pernah melakukan pelaporan & 9 & 100,00 \\
\hline & & - Pemrakarsa rutin melakukan pemantauan & - & \\
\hline & Pemantauan & $\begin{array}{l}\text { - Pemrakarsa melakukan pemantauan tetapi } \\
\text { tidak rutin }\end{array}$ & - & \\
\hline & & $\begin{array}{l}\text { - Pemrakarsa tidak pernah melakukan } \\
\text { pemantauan }\end{array}$ & 9 & 100,00 \\
\hline
\end{tabular}

Tabel 3. Pelaksanaan dokumen UKL-UPL pada Dinas Pekerjaan Umum dan Tata Ruang Kota Palangka Raya

\begin{tabular}{|c|c|c|c|c|}
\hline Variabel & Kriteria & Sub Kriteria & Frekuensi & Persentase (\%) \\
\hline \multirow{9}{*}{$\begin{array}{l}\text { Dokumen UKL } \\
\text { dan UPL }\end{array}$} & \multirow{3}{*}{ Kepemilikan } & - Ada & - & \\
\hline & & - Dalam proses & - & \\
\hline & & - Tidak ada & 3 & 100,00 \\
\hline & \multirow{3}{*}{ Implementasi } & - Semua isi dokumen dilaksanakan & - & \\
\hline & & - Sebagian dokumen dilaksanakan & - & \\
\hline & & - Tidak dilaksanakan & 3 & 100,00 \\
\hline & \multirow{3}{*}{ Pelaporan } & - Rutin melakukan pelaporan & - & \\
\hline & & - Melakukan pelaporan tetapi tidak rutin & - & \\
\hline & & - Tidak pernah melakukan pelaporan & 3 & 100,00 \\
\hline
\end{tabular}


Tabel 4. Pelaksanaan dokumen UKL-UPL pada Pengelola Pasar Kahayan/ UPTD Pasar Pemerintah

\begin{tabular}{|c|c|c|c|c|}
\hline Variabel & Kriteria & Sub Kriteria & Frekuensi & Persentase (\%) \\
\hline \multirow{9}{*}{$\begin{array}{l}\text { Dokumen } \\
\text { UKL dan } \\
\text { UPL }\end{array}$} & \multirow{3}{*}{ Kepemilikan } & - Ada & - & \\
\hline & & - Dalam proses & - & \\
\hline & & - Tidak ada & 3 & 100,00 \\
\hline & \multirow{3}{*}{ Implementasi } & - Semua isi dokumen dilaksanakan & - & \\
\hline & & - Sebagian dokumen dilaksanakan & - & \\
\hline & & - Tidak dilaksanakan & 3 & 100,00 \\
\hline & \multirow{3}{*}{ Pelaporan } & - Rutin melakukan pelaporan & - & \\
\hline & & - Melakukan pelaporan tetapi tidak rutin & - & \\
\hline & & - Tidak pernah melakukan pelaporan & 3 & 100,00 \\
\hline
\end{tabular}

Tabel 3 menunjukkan bahwa pelaksanaan Dokumen UKL-UPL pada Dinas Pekerjaan Umum dan Penataan Ruang Kota Palangka Raya pada kriteria kepemilikan tidak ada (100\%), implementasinya tidak dilaksanakan (100)\%, serta tidak pernah melakukan pelaporan (100\%). Hasil penelitian dapat disimpulkan bahwa laporan pemantauan yang dilakukan oleh pelaksanaan Dokumen UKL-UPL pada Pada Dinas Pekerjaan Umum dan Tata Ruang Kota Palangka Raya tidak pernah dilaksanakan. Evaluasi pengelolaan dan pemantauan tidak pernah dilaksanakan.

Tabel 4 menunjukkan bahwa pelaksanaan Dokumen UKL-UPL pada Pengelola Pasar Kahayan/UPTD Pasar Pemerintah pada kriteria kepemilikan tidak ada (100\%), implementasinya tidak dilaksanakan (100\%), serta tidak pernah melakukan pelaporan (100\%). Hasil penelitian dapat disimpulkan bahwa laporan pemantauan yang dilakukan oleh pelaksanaan Dokumen UKL-UPL pada Pengelola Pasar Kahayan/UPTD Pasar Pemerintah tidak pernah dilaksanakan. Evaluasi pengelolaan dan pemantauan tidak pernah dilaksanakan.

\subsection{Indikator Pelaksanaan Pengelolaan dan Pemantauan}

Evaluasi pelaksanaan pengelolaan dan pemantauan lingkungan hidup dampak pembangunan Pasar Kahayan Kota Palangka Raya adalah menggunakan indikator persepsi masyarakat, kualitas air dan biota perairan.

\section{- Persepsi Masyarakat}

Jumlah Responden yang diwawancarai sebanyak 40 orang, masing-masing 20 orang masyarakat sekitar, 10 orang pemilik toko dan 10 orang konsumen.

Tabel 5. Profesi responden kelompok masyarakat

\begin{tabular}{clcc}
\hline No. & \multicolumn{1}{c}{ Pekerjaan } & $\begin{array}{c}\text { Jumlah } \\
\text { (Orang) }\end{array}$ & $\begin{array}{c}\text { Presentase } \\
\text { (\%) }\end{array}$ \\
\hline 1. & Pegawai Negeri Sipil & 1 & $5 \%$ \\
2. & Pedagang & 7 & $35 \%$ \\
3. & Swasta & 5 & $5 \%$ \\
4. & Buruh Bangunan & 3 & $15 \%$ \\
5. & Ibu Rumah Tangga & 4 & $4 \%$ \\
\hline & Jumlah & $\mathbf{2 0}$ & $\mathbf{4 \%}$ \\
\hline
\end{tabular}

Tabel 6. Profesi responden kelompok pedagang

\begin{tabular}{clcc}
\hline No. & \multicolumn{1}{c}{ Pekerjaan } & $\begin{array}{c}\text { Jumlah } \\
\text { (orang) }\end{array}$ & $\begin{array}{c}\text { Presentase } \\
\text { (\%) }\end{array}$ \\
\hline 1. & Pedagang Ikan & 2 & 20 \\
2. & Pedagang Ayam & 2 & 20 \\
3. & Pedagang Sembako & 2 & 20 \\
4. & Pedagang Sayur & 2 & 20 \\
5. & Pedagang Baju & 1 & 10 \\
6. & Apotik & 1 & 10 \\
\hline \multicolumn{4}{r}{ Jumlah } \\
\hline
\end{tabular}

Tabel 7. Tingkat pendidikan responden

\begin{tabular}{clcc}
\hline No. & Tingkat Pendidikan & $\begin{array}{c}\text { Jumlah } \\
\text { (orang) }\end{array}$ & $\begin{array}{c}\text { Persentase } \\
\text { (\%) }\end{array}$ \\
\hline 1. & Sekolah Dasar & 6 & 15,0 \\
2. & $\begin{array}{l}\text { Sekolah Menengah } \\
\text { Pertama }\end{array}$ & 6 & 15,0 \\
3. & $\begin{array}{l}\text { Sekolah Menengah } \\
\text { Atas/Kejuruan }\end{array}$ & 25 & 62,5 \\
4. & Sarjana & 3 & 7,5 \\
\hline & \multicolumn{1}{c}{ Jumlah } & $\mathbf{4 0}$ & $\mathbf{1 0 0 , 0}$ \\
\hline
\end{tabular}

Persepsi masyarakat terhadap pemanfataan pasar, fisik dan pengelolaan pasar maka dapat disimpulkan dengan persepsi Baik. Dari hasil kuesioner persepsi masyarakat masih terdapat beberapa responden yang tidak setuju terhadap beberapa pernyataan fisik antara lain bahwa kondisi jalan menuju pasar dalam kondisi baik sedangkan pada kenyataannya kondisi jalan menuju pasar kurang baik dan ada yang berlobang. Apabila turun hujan akan sangat membahayakan karena adanya genangan air. Untuk pernyataan fisik yang lain pada lahan parkir yang tidak cukup untuk menampung kendaraan. Sedangkan untuk pengelolaan pasar ada 1 (satu) responden menjawab tidak setuju ikut dalam kegiatan kebersihan pasar alasannya karena sudah ada pengelola yang menangani kebersihan pasar. 
Tabel 8. Persepsi masyarakat terhadap pemanfaatan pasar, fisik dan pengelolaan pasar

\begin{tabular}{clcc}
\hline No. & Aspek & Skor (\%) & Persepsi \\
\hline 1. & Pemanfaatan & 69 & Baik \\
2. & Fisik & 41 & Cukup \\
3. & Pengelolaan & 46 & Cukup \\
\hline
\end{tabular}

Persepsi Pedagang terhadap aspek pemanfaatan pasar dengan nilai 54\% dengan Persepsi Baik, sedangkan Pengelolaan dengan nilai terendah yaitu $50 \%$ dengan persepsi kategori Cukup dengan hasil wawancara bahwa perlu ditingkatkan kebersihan pasar dan untuk fisik pasar dengan nilai $58 \%$ dengan pandangan persepsi pedagang kategori baik tetapi ada saran dari pedagang bahwa perlu adanya rehap dan perbaikan sarana prasarana pasar dikarenakan kondisi atap bangunan pasar ada yang bocor. Dari hasil kuesioner persepsi pedagang masih terdapat beberapa responden yang kurang setuju terhadap beberapa perny, ataan antara lain kurang setuju dalam pernyataan tempat pembuangan sampah sudah terpenuhi tetapi pada kenyataannya masih ada sampah yang berserakan sehingga perlu ada penambahan tongtong sampah.

Tabel 9. Persepsi pedagang terhadap pemanfaatan, fisik dan pengelolaan pasar Kahayan

\begin{tabular}{clcc}
\hline No. & \multicolumn{1}{c}{ Aspek } & Skor (\%) & Persepsi \\
\hline 1. & Pemanfaatan Pasar & 54 & Baik \\
2. & Fisik Pasar & 58 & Baik \\
3. & Pengelolaan Pasar & 50 & Cukup \\
\hline
\end{tabular}

Data persepsi konsumen terhadap pemanfaatan pasar dengan nilai 53\% dengan persepsi konsumen baik, sedangkan fisik dengan nilai terendah yaitu $40 \%$ dengan persepsi terhadap pandangan konsumen kategori Cukup. Kondisi jalan menuju pasar rusak dan pengelolaan pasar dengan nilai $50 \%$ dengan pandangan persepsi konsumen kategori Cukup. Terdapat beberapa responden yang kurang setuju terhadap beberapa pernyataan antara lain kurang setuju tempat parkir yang dinyatakan cukup luas, kurang setuju jalan menuju pasar cukup baik dan kurang setuju tingkat keamanan yang dinyatakan cukup baik, tetapi pernyataan diatas tidak mengurangi nilai responden yang setuju terhadap beberapa pernyataan.

Tabel 10. Persepsi konsumen terhadap pemanfaatan, fisik dan pengelolaan pasar Kahayan

\begin{tabular}{clcc}
\hline No. & \multicolumn{1}{c}{ Aspek } & Skor & Persepsi \\
\hline 1. & Pemanfaatan Pasar & $53 \%$ & Baik \\
2. & Pengelolaan Pasar & $50 \%$ & Cukup \\
3. & Fisik & $40 \%$ & Cukup \\
\hline
\end{tabular}

\section{- Kualitas Air Permukaan}

Hasil analisis laboratorium terhadap kualitas air permukaan dari outlet pembuangan air limbah pasar Kahayan dan pengaringan atau drainase besar sebagai penampung buangan air limbah domestik dari pasar kahayan dan rumah tangga dibandingkan dengan Peraturan Pemerintah Republik Indonesia Nomor 82 Tahun 2001 tentang Pengelolaan Kualitas Air dan Pengendalian Pencemaran Air, serta Peraturan Menteri Lingkungan Hidup dan Kehutanan Republik Indonesia Nomor P.68/Menlhk-Setjen/2016 tentang Baku Mutu Air Limbah Domestik. Rinciannya disajikan pada Tabel 11.

\section{PEMBAHASAN}

Pasar sebagai suatu tempat perdagangan merupakan sumber timbunan sampah dan limbah cair dari kawasan komersial. Sebagai sebuah pusat perdagangan, pasar selalu berada di lokasi yang strategis, bahkan banyak dijumpai letak pasar berada di pusat kota. Pasar mempunyai potensi yang cukup besar untuk menimbulkan sampah dan limbah cair. Limbah cair Pasar Kahayan yang berasal dari aktivitas pencucian lantai, pencucian barang-barang dagangan (sayur-sayuran, buah-buahan, daging, dan ikan), pencucian lapak-lapak jualan, penggilingan daging, serta aktivitas MCK yang dialirkan kesaluran pengumpul setelah itu dibuang kebadan air atau drainase terdekat.

\subsection{Parameter Fisik}

- Temperatur Air $\left({ }^{\circ} \mathrm{C}\right)$

Hasil penelitian menunjukan suhu air masih dikategorikan normal untuk suhu air permukaan dan kisaran suhu yang umum dijumpai di daerah tropis seperti wilayah kota Palangka Raya. Perbedaan suhu air antara outlet dan badan sungai atau drainase relatif kecil. Hal ini diperkirakan bahwa buangan limbah cair dari pasar Kahayan tidak berpotensi merubah suhu perairan sungai penerima limbah. Suhu normal air di alam daerah tropis berkisar antara $20^{\circ} \mathrm{C}-30^{\circ} \mathrm{C}$ untuk kehidupan hewan air dan organisme air lainnya (Suripin, 2002). Dengan demikian kondisi suhu air saat penelitian tidak mengganggu kehidupan hewan dan organisme air lainnya.

\section{- Zat Padat Terlarut (TDS)}

TDS merupakan parameter dari jumlah material yang dilarutkan dalam air dapat mencakup karbonat,

bikarbonat, klorida, sulfat, fosfat, nitrat, kalsium, magnesium, natrium, ion-ion organik, dan ion-ion lainnya. Perubahan dalam konsentrasi TDS dapat berbahaya karena densitas (massa jenis) air menentukan aliran air masuk dan keluar dari sel-sel organisme. Sumber utama TDS pada daerah penelitian diperkirakan berasal dari air limbah yang keluar dari outlet pasar 
Tabel 11. Hasil penelitian parameter kualitas air permukaan

\begin{tabular}{|c|c|c|c|c|c|c|}
\hline \multirow{2}{*}{ No. } & \multirow{2}{*}{ Parameter } & \multirow{2}{*}{ Satuan } & \multirow{2}{*}{$\begin{array}{l}\text { Baku } \\
\text { Mutu }\end{array}$} & \multicolumn{2}{|c|}{ Hasil } & \multirow{2}{*}{ Keterangan } \\
\hline & & & & A-1 & A-2 & \\
\hline \multicolumn{7}{|c|}{ Fisika } \\
\hline 1. & Temperatur Air & $\left({ }^{\circ} \mathrm{C}\right)$ & - & 29 & 27,5 & \multirow[b]{2}{*}{$\begin{array}{l}\text { Tidak melebihi Baku } \\
\text { Mutu }\end{array}$} \\
\hline 2. & Zat Padat Terlarut (TDS) & $\mathrm{mg} / \mathrm{l}$ & 1.000 & 113 & 93 & \\
\hline 3. & Zat Padat Tersuspensi (TSS) & $\mathrm{mg} / \mathrm{l}$ & 50 & 30 & 125 & A-2 melebihi Baku Mutu \\
\hline II. & Kimia & & & & & \multirow[b]{4}{*}{$\begin{array}{l}\text { Tidak melebihi Baku } \\
\text { Mutu }\end{array}$} \\
\hline 1. & Derajat Keasaman $(\mathrm{pH})$ & & - & 6,88 & 5,15 & \\
\hline 2. & Oksigen terlarut (DO) & $\mathrm{mg} / \mathrm{l}$ & - & 4,0 & 3,1 & \\
\hline 3. & Minyak dan Lemak & $\mathrm{mg} / \mathrm{l}$ & 1.000 & $<200$ & $<200$ & \\
\hline 4. & Detergen (MBAS) & $\mu g / l$ & 200 & $<10$ & 6.270 & A-2 melebihi Baku Mutu \\
\hline 5. & Biochemical Oxygen Demand $\left(\mathrm{BOD}_{5}\right)$ & $\mathrm{mg} / \mathrm{l}$ & 3 & 16 & 56 & \multirow{2}{*}{ Melebihi Baku Mutu } \\
\hline 6. & Chemical Oxygen Demand (COD) & $\mathrm{mg} / \mathrm{l}$ & 25 & 64 & 168 & \\
\hline 7. & Nitrit $\left(\mathrm{NO}_{2}-\mathrm{N}\right)$ & $\mathrm{mg} / \mathrm{l}$ & 0,06 & 1 & $<0,002$ & A-1 melebihi Baku Mutu \\
\hline 8. & Nitrat $\left(\mathrm{NO}_{3}-\mathrm{N}\right)$ & $\mathrm{mg} / \mathrm{l}$ & 10 & 3 & $<0,1$ & $\begin{array}{l}\text { Tidak melebihi Baku } \\
\text { Mutu }\end{array}$ \\
\hline 9. & Fosfat Total & $\mathrm{mg} / \mathrm{l}$ & 0,2 & 0,8 & 1 & \multirow[t]{4}{*}{ Melebihi Baku Mutu } \\
\hline 10. & Boron (B) & $\mathrm{mg} / \mathrm{l}$ & 1 & $<0,02$ & 0,5 & \\
\hline 11. & Kobalt (Co) & $\mathrm{mg} / \mathrm{l}$ & 0,2 & $<0,0007$ & $<0,0007$ & \\
\hline 12. & Khlorin Bebas $\left(\mathrm{Cl}_{2}\right)$ & $\mathrm{mg} / \mathrm{l}$ & - & $<0,01$ & $<0,01$ & \\
\hline 13. & Tembaga (Cu) & $\mathrm{mg} / \mathrm{l}$ & 0,02 & $<0,005$ & $<0,005$ & \multirow{5}{*}{$\begin{array}{l}\text { Tidak melebihi Baku } \\
\text { Mutu }\end{array}$} \\
\hline 14. & Air Raksa (Hg) & $\mathrm{mg} / \mathrm{l}$ & 0,002 & $<0,0005$ & $<0,0005$ & \\
\hline 15. & Kadmium (Cd) & $\mathrm{mg} / \mathrm{l}$ & 0,01 & $<0,0006$ & $<0,0006$ & \\
\hline 16. & Timbal (Pb) & $\mathrm{mg} / \mathrm{l}$ & 0,03 & $<0,009$ & $<0,009$ & \\
\hline 17. & Seng $(Z n)$ & $\mathrm{mg} / \mathrm{l}$ & 0,05 & 0,004 & 0,03 & \\
\hline III. & \multicolumn{5}{|l|}{ Mikrobiologi } & \multirow{3}{*}{ Melebihi Baku Mutu } \\
\hline 1. & Koliform Tinja & $\begin{array}{l}\text { MPN/10 } \\
0 \mathrm{ml}\end{array}$ & 1.000 & 9.200 & 54.000 & \\
\hline 2. & Total Kolifrom & $\begin{array}{l}\mathrm{MPN} / 10 \\
0 \mathrm{ml}\end{array}$ & 5.000 & 16.000 & 92.000 & \\
\hline
\end{tabular}

Kahayan dan dari kegiatan domestik masyarakat yang bermukim disepanjang sungai atau drainase. Secara umum sumber TDS pada badan air berasal dari limpasan pertanian dan perumahan, pencucian tanah oleh aktivitas manusia.

\section{- Zat Padat Tersuspensi (TSS)}

Zat Padat Tersuspensi (Total Suspended Solid) adalah semua zat padat (pasir, lumpur, dan tanah liat) atau partikel-partikel yang tersuspensi dalam air dan dapat berupa komponen hidup (biotik). Kandungan TSS pada air di Titik Sampling A-2 telah melebihi Baku Mutu air kelas II yang dipersyaratkan, yaitu 50 mg/l (PP No. 82 tahun 2001). Sedangkan berdasarkan Peraturan Menteri Lingkungan Hidup dan Kehutanan Republik Indonesia Nomor P.68/Menlhk-Setjen/2016 tentang Baku Mutu Air Limbah Domestik, kandungan TSS pada Titik Sampling A2 telah melebihi Baku Mutu yang dipersyaratkan, yaitu 30 mg/l. Titik Sampling A-2 sebagai outlet limbah cair dari aktivitas pasar menghasilkan TSS yang cukup tinggi dikarenakan pasar Kahayan menghasilkan buangan cair dan padat yang besar. Jenis usaha didalam pasar Kahayan seperti penjual ikan, ayam, sayuran, sembako, daging, penggilingan daging, dan berbagai macam dagangan. Oleh karena itu kandungan TSS yang melebihi baku mutu yang dipersyaratakan harus perlu 
pengelolaan dan pemantauan lebih lanjut oleh Pemrakarsa, agar air yang dikeluarkan tidak mencemari badan perairan yang pada akhirnya berdampak kepada kesehatan manusia dan masyarakat sekitar.

\subsection{Parameter Kimia}

- Derajat Keasaman $(\mathrm{pH})$ air

Derajat keasaman $(\mathrm{pH})$ merupakan indeks kadar ion hidrogen $\left(\mathrm{H}^{+}\right)$yang mencirikan keseimbangan asam dan basa. Nilai $\mathrm{pH}$ merupakan salah satu faktor yang mempengaruhi produktivitas perairan. Nilai $\mathrm{pH}$ dalam suatu perairan dapat juga dijadikan indikator dari adanya keseimbangan unsur-unsur kimia dan hara yang sangat bermanfaat bagi kehidupan vegetasi akuatik. Tinggi rendahnya $\mathrm{pH}$ dipengaruhi oleh fluktuasi kandungan $\mathrm{O}_{2}$ maupun $\mathrm{CO}_{2}$. Derajat keasaman $(\mathrm{pH})$ perairan dipengaruhi oleh suhu, fotosintesa, respirasi, oksigen terlarut, dan keberadaan ion-ion dalam perairan. Kelarutan logam dalam air juga dikontrol oleh $\mathrm{pH}_{\text {, }}$ kenaikan $\mathrm{pH}$ air akan menurunkan larutan logam dalam air. Tingkat $\mathrm{pH}$ lebih kecil dari 4,8 dan lebih besar dari 9,2 sudah dapat dianggap tercemar (Alaerts dan Santika, 1984). Menurut penelitian Estri Aurorina tahun 1996, nilai $\mathrm{pH}$ pada limbah pemotongan Rumah Pemotongan Hewan (RPH) Semarang antara 6,7-7,1, sedangkan Komariah (2011) dalam penelitiannya terhadap limbah lateks pada industri karet menunjukkan nilai $\mathrm{pH} 3,5-4,5$.

\section{- Oksigen terlarut (DO)}

Kandungan oksigen terlarut (DO) berdasarkan PP No. 82 tahun 2001, konsentrasi DO yang persyaratkan minimum $4 \mathrm{mg} / \mathrm{l}$. Kandungan oksigen terlarut minimum ini sudah cukup mendukung kehidupan organisme. Oksigen terlarut (DO) dalam perairan dipengaruhi oleh proses dekomposisi bahan organik dan oksidasi bahan anorganik. Oksigen terlarut juga memegang peranan penting sebagai indikator kualitas perairan, karena oksigen terlarut berperan dalam proses oksidasi dan reduksi bahan organik dan anorganik. Dalam kondisi aerobik, peranan oksigen adalah untuk mengoksidasi bahan organik dan anorganik dengan hasil akhirnya adalah nutrien yang dapat memberikan kesuburan perairan (Effendi, 2003).

\section{- Minyak dan Lemak}

Kandungan minyak dan lemak yang terdapat dalam limbah cair bersumber dari aktivitas pasar Kahayan seperti los pasar ikan, ayam, daging, penggilingan daging, dan pembersihan lantai pasar. Kandungan minyak dan lemak yang cukup tinggi dapat mempengaruhi aktivitas mikroorganisme dalam mendegradasi limbah (Supriyadi dan Karnaningroem, 2014). Minyak dan lemak merupakan bahan organik bersifat tetap dan sukar diuraikan bakteri. Karena berat jenisnya lebih kecil dari air, maka minyak dan lemak membentuk lapisan tipis dipermukaan air dan menutup permukaan yang mengakibatkan terbatasnya oksigen masuk kedalam air (Ginting, 2007). Minyak yang menutupi permukaan air akan menghalangi penetrasi sinat matahari kedalam air, serta dapat mengurangi konsentrasi oksigen terlarut di dalam air karena fiksasi oksigen bebas terhambat (Nugroho, 2006).

\section{- Detergen (MBAS)}

Deterjen merupakan bahan yang mengandung Methylene Blue Active Substance (MBAS) yang banyak dipakai masyarakat untuk kegiatan sehari-hari. Surfaktan -zat aktif permukaan atau tensides adalah zat yang menyebabkan turunnya tegangan permukaan cairan, khususnya air. Ini menyebabkan pembentukan gelembung dan pengaruh permukaan lainnya yang memungkinkan zat-zat ini bertindak sebagai zat pembersih atau penghambur dalam industri dan untuk tujuan rumah tangga (Connell dan Miller, 1995). Surfaktan atau surface active agent atau wetting agent merupakan bahan organik yang berperan sebagai bahan aktif pada deterjen, sabun dan shampoo. Surfaktan dapat menurunkan tegangan permukaan sehingga memungkin -kan partikel-partikel yang menempel pada bahan-bahan yang dicuci terlepas dan mengapung atau terlarut dalam air (Effendi, 2003). Sumber utama pencemaran deterjen berasal dari limbah domestik, sisa buangan deterjen lebih tahan dan tidak berubah dalam berbagai media baik dalam media asam dan alkali, lebih spesifik dari deterjen adalah bahan pembersih yang mengandung senyawa petrokimia atau surfaktan sintetik lainnya. Surfaktan merupakan bahan pembersih utama yang terdapat didalam deterjen (Riza et al., 2015). Meskipun tidak bersifat toksik, keberadaan surfaktan dapat menimbulkan rasa pada air dan dapat menurunkan absorpsi oksigen di perairan (Effendi, 2003).

\section{- Biochemical Oxygen Demand $\left(\mathrm{BOD}_{5}\right)$}

Biochemical Oxygen Demand $\left(\mathrm{BOD}_{5}\right)$ merupakan gambaran kadar bahan organik, yaitu jumlah oksigen terlarut yang dibutuhkan oleh mikroba aerob untuk mengoksidasi bahan organik menjadi karbondioksida didalam air. Berdasarkan hasil penelitian kandungan BOD pada air telah melebihi Baku Mutu air kelas II yang dipersyaratkan yaitu 3 mg/l (Baku Mutu Kelas II Peraturan Pemerintah Republik Indonesia No. 82 Tahun 2001). Berdasarkan Peraturan Menteri Lingkungan Hidup dan Kehutanan Republik Indonesia Nomor P.68/MenlhkSetjen/2016 tentang Baku Mutu Air Limbah Domestik, kandungan BOD pada Titik Sampling A-2 telah melebihi Baku Mutu yang dipersyaratkan, yaitu $30 \mathrm{mg} / \mathrm{l}$. Titik Sampling A-2 merupakan saluran pembuangan langsung/outlet limbah dari aktivitas pasar Kahayan. Apabila dibandingkan dengan kandungan oksigen terlarut hasil pengukuran langsung (insitu) pada kedua titik diperoleh hasil oksigen terlarut pada Titik Sampling A-2 lebih kecil dibandingkan dengan Titik Sampling A-1, hal ini diduga karena mikroba aerob pada outlet limbah 
pasar Kahayan membutuhkan oksigen terlarut lebih banyak untuk mengoksidasi bahan organik. Nilai kandungan BOD sangat tergantung pada kadar oksigen didalam air. $\mathrm{BOD}_{5}$ dapat mencerminkan tingakat pencemaran suatu badan perairan oleh buangan organik, semakin tinggi nilai $\mathrm{BOD}_{5}$, berarti semakin besar tingkat pencemaran (Pamungkas, 2016).

\section{- Chemical Oxygen Demand (COD)}

Chemical Oxygen Demand (COD) adalah jumlah oksigen yang diperlukan agar bahan buangan yang ada dalam air dapat teroksidasi melalui reaksi kimia, baik yang dapat didegradasi secara biologis maupun yang sukar didegradasi. COD sebagai jumlah oksigen yang diperlukan untuk mengoksidasi bahan buangan, diperkirakan tingginya konsetrasi COD disebabkan karena bahan organik dan anorganik yang dihasilkan dari aktivitas pasar Kahayan yang menyebabkan konsumsi oksigen terlarut semakin meningkat. Adanya bahan organik yang teroksidasi secara kimia menyebabkan jumlah oksigen yang diperlukan semakin besar (Indarsih at al., 2011).

- Koliform Tinja dan Total Kolifrom

Kualitas limbah cair Pasar Kahayan secara bakteriologis menunjukkan adanya kandungan kolifrom tinja total dan kolifrom. Hal ini diduga karena adanya mikroorganisme patogen baik virus maupun bakteri. Coliform merupakan golongan bakteri yang termasuk ke dalam famili Enterobacteriaceae yang hidup disaluran pencernaan manusia dan hewan. Coliform digunakan sebagai indikator adanya kontaminasi feses manusia dan hewan serta kondisi sanitasi yang tidak baik. Bakteri Coliform dibedakan kedalam 2 kelompok yaitu kelompok Coliform fekal dan Coliform non-fekal. Coliform fekal adalah bakteri yang berasal dari tinja manusia atau hewan berdarah panas. Coliform non-fekal adalah bakteri yang ditemukan pada hewan atau tanaman yang telah mati. Sedangkan Total coliforms adalah termasuk bakteri yang dapat ditemukan dilingkungan tanah dan air yang telah terpengaruh oleh air permukaan serta limbah pembuangan kotoran manusia dan hewan. Aktivitas Pasar Kahayan menghasilkan buangan cair dan padat yang besar dari berbagai jenis usaha dilakukan di dalam pasar Kahayan dari penjual ikan, ayam, sayuran, sembako, daging, penggilingan daging, dan berbagai macam dagangan lagi.

- Nitrit $\left(\mathrm{NO}_{2}-\mathrm{N}\right)$, Nitrat $\left(\mathrm{NO}_{3}-\mathrm{N}\right)$, Fosfat Total, Boron (B), Kobalt (Co), dan Khlorin Bebas $\left(\mathrm{Cl}_{2}\right)$

Nitrit $\left(\mathrm{NO}_{2}\right)$ merupakan bentuk peralihan antara ammonia dan nitrat (nitrifikasi) dan antara nitrat dengan gas nitrogen (denitrifikasi) oleh karena itu nitrit bersifat tidak stabil dengan keberadaan oksigen. Kandungan nitrit pada perairan alami sekitar 0,001 mg/l. Kadar nitrit yang lebih dari $0,06 \mathrm{mg} / \mathrm{l}$ akan bersifat toksik bagi organisme perairan. Sedangkan pada Titik Sampling A-2 parameter yang melebihi baku mutu adalah Fosfat Total $\left(\mathrm{PO}_{4}\right)$, yaitu $1 \mathrm{mg} / \mathrm{l}$. Fosfat adalah bentuk fosfor yang dapat dimanfaatkan oleh tumbuhan dan merupakan unsur esensial bagi tumbuhan tingkat tinggi dan alga sehingga dapat mempengaruhi tingkat produktivitas perairan (Bahri, 2006). Konsentrasi fosfat pada Titik Sampling A-2 atau outlet limbah cair dari Pasar Kahayan telah melebihi baku mutu, hal ini diperkirakan terjadi karena aliran limbah cair yang membawa deterjen, serta sisa-sisa bahan organik dan anorganik hasil dari aktivitas pasar Kahayan.

- Logam Berat Tembaga (Cu), Air Raksa (Hg), Kadmium (Cd), Timbal (Pb) dan Seng (Zn)

Tembaga (Cu), Air Raksa (Hg), Kadmium (Cd), Timbal $(\mathrm{Pb})$ dan Seng $(\mathrm{Zn})$ termasuk kedalam golongan logam berat. Secara keseluruhan hasil analisis laboratorium kualitas air dikedua Titik Sampling menunjukkan tidak ada melebihi ambang batas baku mutu Kriteria Baku Mutu Air Kelas II Menurut PP No. 82 Tahun 2001 yang dipersyaratkan. Sehingga keberadaan kandungan logam berat di perairan tidak membahayakan, namun tetap perlu diperhatikan karena logam - logam tersebut memiliki dampak negatif terhadap manusia jika dikonsumsi dalam jumlah yang besar dan waktu yang lama. Logam berat terdapat dalam bentuk terlarut dan tersuspensi. Berdasarkan kegunaannya ada golongan logam berat yang pada konsentrasi tertentu berfungsi sebagai mikronutrien yang bermanfaat bagi organisme perairan seperti Zn, Fe, Cu dan Co yang dibutuhkan oleh organisme untuk pertumbuhan dan perkembangan hidupnya (Yudo, 2006).

\section{- Amoniak $\left(\mathrm{NH}_{3}-\mathrm{N}\right)$}

Amoniak $\left(\mathrm{NH}_{3}\right)$ merupakan salah satu bahan kimia yang berbentuk bebas berupa gas, dan yang terlarut dalam air sebagai larutan amonium hidroksida $\left(\mathrm{NH}-{ }_{4} \mathrm{OH}\right)$. Secara alami amoniak dapat terbentuk dari hasil penguraian protein pada pembusukan limbah atau sampah organik. Disamping berbau busuk, adanya gas amoniak di udara dapat mencemari lingkungan dan berakibat gangguan kesehatan bagi manusia yang sering menghirup amoniak (Banon dan Suharto, 2008). Amoniak bebas yang tidak terionisasi bersifat toksik bagi organisme akuatik. Toksisitas amoniak terhadap organisme akuatik akan meningkat jika terjadi penurunan kadar oksigen terlarut, $\mathrm{pH}$, dan suhu (Effendi, 2003).

Titik Sampling A-2 sebagai outlet limbah cair dari pasar kahayan merupakan saluran pembuangan akhir dari limbah yang dihasilkan oleh pasar kahayan, sehingga peningkatan amoniak $\left(\mathrm{NH}_{3}\right)$ sangat mungkin terjadi. Sedangkan tingginya konsentrasi amoniak di badan air/ drainase (Titik Sampling A-1) mengindikasikan adanya pencemaran yang salah satunya disebabkan oleh buangan air limbah domestik yang diolah maupun yang tidak diolah. Pada konsentrasi $\mathrm{NH}_{3} 1 \mathrm{mg} / \mathrm{l}$ beberapa jenis ikan akan mati lemas karena amonia 
dapat mengurangi konsetrasi oksigen dalam air (Hibban et al., 2016).

\subsection{Biota Perairan}

Rendahnya kelimpahan fitoplankton ini disebabkan karena kondisi lingkungan perairan tidak mendukung kehidupan fitoplankton dengan baik. Berdasarkan hasil tersebut diperoleh jumlah organisme Cyanophyta lebih banyak dari Chloropyta, Chrysophyta, dan Bacillariophyceae. Diperkirakan kondisi badan air/sungai penerima limbah pasar Kahayan tergolong kurang baik atau tercemar karena limbah domestik rumah tangga, usaha-usaha masyarakat dan pasar Kahayan yang membuang limbahnya ke badan air/sungai penerima limbah. Menurut Suharto (2014), suatu perairan apabila didominasi oleh divisi Cyanophyta maka perairan tersebut termasuk yang tercemar yang dapat menyebabkan gangguan terhadap kehidupan akuatik.

Jenis zooplankton yang ditemukan adalah filum Euglenophyta dengan jenis Euglena gracilis dengan jumlah 8 individu/liter, filum Ciliata dengan jenis Phacus sp. dengan jumlah 40 individu/liter, dan filum Rotifera dengan jenis Notholca sp. dengan jumlah 24 individu/ liter. Rotifera merupakan zooplankton yang dapat ditemukan di perairan tawar maupun payau. Rotifera dapat berkembang biak jika perairan mengandung bahan organik Sachlan, 1982). Hasil analisis Laboratorium menunjukkan organisme jenis Benthos tidak ditemukan atau tidak terdeteksi pada saat kegiatan penelitian ini. Jenis organisme yang dapat digunakan menjadi indikator kualitas lingkungan perairan adalah dari filum Bacillariophycea yaitu organisme Navicula. Navicula merupakan organisisme yang mampu bertahan hidup pada kondisi yang buruk atau tempat - tempat yang telah mengalami pencemaran limbah seperti limbah rumah tanggga, limbah pertanian dan zat kimia lainnya. Kelas Bacillariophyceae merupakan kelompok alga yang mudah beradaptasi dengan lingkungan dan penyebarannya luas, serta merupakan bagian terpenting dari organisme air karena merupakan makanan bagi zooplankton atau hewan air lainnya, serta Navicula toleran terhadap perubahan lingkungan dari perairan bersih sampai tercemar berat (Widiana, 2012).

Indeks keanekaragaman jenis $\left(\mathrm{H}^{\prime}\right)$ fitoplankton pada kedua titik sampling yaitu 1,2641 dan 1,6204 sehingga diperoleh indeks keanekaragaman sedang pada $\left(1<\mathrm{H}^{\prime}<3\right.$ ). Indeks keanekaragaman mengacu kepada dua prinsif ekologi yaitu batas toleransi dan kompetisi (ruang dan makanan). Organisme dalam suatu wilayah ekologi mempunyai batas toleransi yang berbeda terhadap perubahan ke arah lingkungan yang buruk. Plankton mempunyai sifat selalu bergerak dapat dijadikan indikator pencemaran perairan. Plankton akan bergerak mencari tempat yang sesuai ketika terjadi pencemaran yang mengubah kondisi tempat hidup awal. Perubahan susunan komunitas organisme yang terjadi dapat dijadikan petunjuk terjadinya pencemaran di perairan. Beberapa organisme plankton bersifat toleran dan mempunyai respon yang berbeda terhadap perubahan kualitas perairan. Penggunaan plankton sebagai indikator kualitas lingkungan perairan dapat dipakai dengan mengetahui keragaman dan keseragaman jenisnya. Penggunaan organisme indikator seperti fitoplankton dalam penentuan kualitas air sangat bermanfaat karena organisme tersebut akan memberikan reaksi terhadap kondisi kualitas perairan.

\section{KESIMPULAN}

Nilai skor persepsi mayarakat, pedagang dan konsumen:

a. Persepsi masyarakat terhadap pemanfaatan pasar sebesar 69\% (Baik), Fisik Pasar 41\% (Cukup), Pengelolaan Pasar 46\% (Cukup).

b. Persepsi pedagang terhadap pemanfaatan pasar

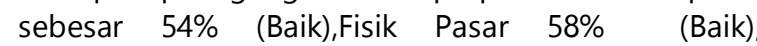
Pengelolaan Pasar 50\% (Cukup).

c. Persepsi konsumen terhadap pemanfaatan pasar sebesar 53\% (Baik), Fisik Pasar 50\% (Baik), Pengelolaan Pasar 40\% (Cukup).

Pelaksanaan dokumen UKL-UPL pada Dinas Pekerjaan Umum dan Penataan Ruang Kota Palangka Raya sebagai Pemrakarsa dan Pengelola Pasar Kahayan/UPTD Pasar Pemerintah untuk implementasinya tidak dilaksanakan; tidak pernah melakukan pelaporan dan evaluasi pengelolaan dan pemantauan.

Parameter zat padat tersuspensi (TSS) pada titik sampling A-2 telah melebihi baku mutu air Kelas II yang dipersyaratkan, yaitu 50 mg/l (PP No. 82 tahun 2001), sehingga perlu pengelolaan dan pemantauan lebih lanjut oleh Pemrakarsa. Parameter kimia yang telah melebihi baku mutu air Kelas II yang dipersyaratkan (PP No. 82 tahun 2001) adalah kandungan BOD, COD, Total Koliform, Fosfat, Amoniak.

\section{DAFTAR PUSTAKA}

Alaerts, G. dan Santika, S.S., 1984. Metode Penelitian Air. Usaha Nasional, Surabaya.

Badan Pusat Statistik Kota Palangka Raya, 2018. Kota Palangka Raya Dalam Angka 2018.

Banon, C. and Suharto, T.E., 2008. Adsorpsi Amoniak Oleh Adsorben Zeolit Alam Yang Diaktivasi Dengan Larutan Amonium Nitrat. GRADIEN: Jurnal Ilmiah MIPA, 4(2), 354-360.

Connel, D.W. and Miller, G.J., 1995. Kimia dan ekotoksikologi pencemaran. Penerjemah: Koestoer, $Y$. Judul asli: Chemistry and Ecotoxicology Of Pollution.. UI-Press: Jakarta.

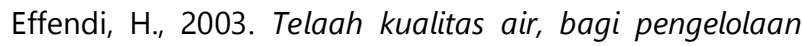
sumber daya dan lingkungan perairan. Kanisius.

Ginting, P., 2007. Sistem Pengelolaan Lingkungan dan 
Limbah Industri. Cetakan Pertama. Yrama Widya, Bandung.

Hibban, M., Rezagama, A. and Purwono, P., 2016. Studi Penurunan Konsentrasi Amonia Dalam Limbah Cair Domestik Dengan Teknologi Biofilter Aerobmedia Tubular Plastik Pada Awal Pengolahan Jurnal Teknik Lingkungan, 5(2), 1-9.

Indarsih, W., Suprayogi, S. and Widiyastuti, M., 2011. Kajian Kualitas Air Sungai Bedog Akibat Pembuangan Limbah Cair Sentra Industri Batik Desa Wijirejo. Majalah Geografi Indonesia, 25(1), 40-54.

Komariah, 2011. Pengaruh Isolat Fungi Trichoderma sp dalamMenurunkan Kadar COD dan BOD Limbah Lateks pada Industri Karet. (Skripsi). Fakultas Kesehatan Masyarakat, Universitas Diponegoro.

Nugroho, A., 2006. Bioindikator Kualitas Air. Universitas Trisakti. Jakarta.

Pamungkas, M.O.A., 2016. Studi pencemaran limbah cair dengan parameter BOD5 dan $\mathrm{pH}$ di pasar ikan tradisional dan pasar modern di kota Semarang. Jurnal Kesehatan Masyarakat (e-Journal), 4 (2), 166-175.

Pemerintah Kota Palangka Raya, 2006. Upaya Pengelolaan Lingkungan Dan Upaya Pemantauan Lingkungan (UKL-UPL) Rehabilitas Pasar Kahayan Kota Palangka Raya.

Peraturan Menteri Lingkungan Hidup Nomor 5 Tahun 2012 Tentang Jenis Rencana Usaha Yang Wajib Amdal.

Peraturan Menteri Lingkungan Hidup Nomor 8 Tahun 2013 Tentang Tata Laksana Penilaian Amdal.

Peraturan Menteri Lingkungan Hidup Nomor 5 Tahun 2014 Tentang Baku Mutu Limbah Cair.

Peraturan Menteri Negara Lingkungan Hidup dan Kehutanan Republik Indonesia Nomor P.23/MENLHK/ SETJEN/KUM.1/7/2018 Tahun 2018 tentang Kriteria Perubahan usaha dan/atau Kegiatan dan Tata Cara Perubahan Izin Lingkungan.

Peraturan Menteri Negara Lingkungan Hidup dan Kehutanan Republik Indonesia Nomor P.24/MENLHK/ SETJEN/KUM.1/7/2018 Tahun 2018 tentang Pengecualian Kewajiban Menyusun AMDAL untuk
Usaha dan/atau Kegiatan Yang Berlokasi Di Daerah Kabupaten/Kota Yang Telah Memiliki Rencana Detail Tata Ruang.

Peraturan Menteri Negara Lingkungan Hidup dan Kehutanan Republik Indonesia Nomor P.25/MENLHK/ SETJEN/KUM.1/7/2018 Tahun 2018 tentang Pedoman Penetapan Jenis Rencana Usaha dan/atau Kegiatan Yang Wajib Memiliki UKL - UPL dan Surat Pernyataan Kesanggupan Pengelolaan dan Pemantauan Lingkungan Hidup.

Peraturan Menteri Negara Lingkungan Hidup Nomor 03 Tahun 2014 tentang Program Penilaian Peringkat Kinerja Perusahaan Dalam Pengelolaan Lingkungan Hidup.

Riza, F., Bambang, A.N. and Kismartini, K., 2015. Tingkat Pencemaran Lingkungan Perairan Ditinjau dari Aspek Fisika, Kimia dan Logam di Pantai Kartini Jepara. Indonesian Journal of Conservation, 4(1), 5260.

Sachlan, M., 1982. Planktonologi. Correspondence Course Centre. Direktorat Jenderal Perikanan, Departemen Pertanian, Jakarta, 141.

Supriyadi, D.B. and Karnaningroem, N., 2014. Kinerja sistem instalasi pengolahan air limbah dengan seri unit anaerobic baffled reactor (ABR) dan anaerobic fileter pada rusunawa. In Proceeding Seminar Nasional Teknologi Praktis dalam Upaya Konservasi Air dan Energi, Teknik Lingkungan ULM (pp. 92-98).

Suripin (watervoorziening.), 2002. Pelestarian sumberdaya tanah dan air. Andi.

Suharto, B., 2014. Analisa Kualitas Perairan Sungai Klinter Nganjuk Berdasarkan Parameter Biologi (Plankton). Jurnal Sumberdaya Alam dan Lingkungan, 1(3), 36-42.

Undang Undang No 32 Tahun 2009 Tentang Perlindungan dan Pengelolaan Lingkungan Hidup.

Widiana, R., 2012. Komposisi fitoplankton yang terdapat di perairan Batang Palangki Kabupaten Sijunjung. Jurnal Pelangi, 5(1), 23-30.

Yudo, S., 2006. Kondisi pencemaran logam berat di perairan sungai DKI Jakarta. Jurnal Air Indonesia, 2(1), $1-15$. 